\title{
ONDERZOEKSNOTITIES
}

\author{
ONDERZOEKSNOTITIE
}

\section{Vrijheidsbeneming in Nederland sinds 1837}

\author{
Een analyse van 180 jaar gevangenisstatistieken
}

Paul Nieuwbeerta

Dit artikel beschrijft op basis van gegevens van de gevangenisstatistieken de ontwikkeling in de periode 1837-2016 van drie kenmerken van het gevangeniswezen: (a) de omvang van de gedetineerdenpopulatie, (b) de omvang van de beschikbare celcapaciteit en (c) de omvang van de instroom van gedetineerden uit de vrije maatschappij. De conclusies zijn tweeledig. Aan de ene kant blijkt dat wanneer de absolute aantallen bekeken worden, er drie zeer verschillende perioden te onderscheiden zijn: eerst zo'n 140 jaar waarin de omvang van het gevangeniswezen - op korte fluctuaties na - stabiel was (1837-1975), vervolgens 30 jaar waarin de omvang van het gevangeniswezen is verdrievoudigd (1975-2005), en daarna ruim 10 jaar waarin deze is gehalveerd (2005-2016). Aan de andere kant blijkt dat wanneer rekening gehouden wordt met de groei van de bevolking, de gehele periode 1837-2016 vooral gekarakteriseerd kan worden als een periode van langdurige daling in vrijheidsbeneming.

\section{Inleiding}

De afgelopen jaren is het aantal gedetineerden in Nederland fors afgenomen (CBS, 2017). Het is echter onduidelijk hoe deze recente daling in vrijheidsbeneming zich verhoudt tot de langetermijnontwikkelingen in ons land. Dit artikel beantwoordt daarom de vraag hoe het aantal gedetineerden en het aantal plaatsen in het gevangeniswezen zich de afgelopen 180 jaar hebben ontwikkeld. Daarnaast beantwoordt het de vraag in hoeverre de ontwikkelingen in absolute aantallen verschillen met de ontwikkelingen in relatieve aantallen, d.w.z. als rekening gehouden wordt met de groei in het aantal inwoners in ons land.

Om de langetermijntrends in vrijheidsbeneming te beschrijven wordt in dit artikel gebruik gemaakt van gegevens van de zogeheten gevangenisstatistieken. Vanaf 1837 zijn deze statistieken vrijwel jaarlijks gepubliceerd - eerst door het ministerie van Binnenlandse Zaken en het ministerie van Justitie en vanaf 1902 door het Centraal Bureau voor de Statistiek (CBS). Desondanks is het veel werk en gepuzzel om vergelijkbare jaarcijfers over de gehele periode vanaf het begin van de gevangenisstatistiek in 1837 te presenteren. Weinigen zijn dan ook die uitdaging aangegaan. 
Er zijn tot dusverre slechts vier eerdere studies verschenen die langetermijntrends in vrijheidsbeneming in Nederland hebben beschreven op basis van de gevangenisstatistieken. De eerste studie is gedaan door Van Ruller (1981a; 1981b). Hij heeft veel werk verricht om alle oude statistieken in kaart te brengen (zie Van Ruller, 1981b). Op basis van deze gegevens laat hij zien dat in de periode 1837-1977 de gevangenispopulatie (zowel op basis van omvang als op basis van celcapaciteit en instroomcijfers) in absolute aantallen vrij stabiel is gebleven. Maar hij laat ook zien dat - omdat in die periode de Nederlandse bevolking vijfmaal zo groot is geworden - het relatieve aantal gedetineerden (per 100.000 inwoners) in die 140 jaar flink is gedaald. Het leek er - zoals Van Ruller later zelf aangaf - eind jaren zeventig op dat 'de gevangenis een langzame dood aan het sterven was, zoals ook met lijfstraffen en doodstraffen in de negentiende eeuw was gebeurd. De gevangenis leek te kunnen worden bijgezet bij de barbaarsheden uit onbeschaafde tijden' (Van Ruller, 2003, 220).

De latere studies laten zien dat deze voorspelling niet uitkwam. De studie van Fiselier $(1987$; 1992) gaf al een eerste aanwijzing voor een historische trendbreuk in vrijheidsbeneming. Deze studie liet zien dat van 1975 tot 1987 zowel het absolute aantal als het relatieve aantal gedetineerden (per 100.000 inwoners) fors omhoog was gegaan. De derde studie, door Van Ruller en Beijers (1995), bevestigde deze ontwikkeling. Deze studie concludeerde dat de gevangenis toch geen langzame dood aan het sterven was, want in de periode 1975-1993 bleek het aantal gevangenen per 100.000 inwoners te zijn verdubbeld. De vierde en laatste studie, verricht door Tonry en Bijleveld (2006), liet zien dat de stijging in het aantal gedetineerden zich in ieder geval heeft doorgezet tot 2005, en dat het aantal gedetineerden per 100.000 inwoners tot die tijd was verdrievoudigd ten opzichte van 1975.

De meest recente studie naar langetermijntrends in vrijheidsbeneming is dus alweer bijna vijftien jaar geleden gepresenteerd. Inmiddels zijn recente cijfers bekend, die aangeven dat sinds 2005 het aantal gedetineerden fors is afgenomen (CBS, 2017). Het is dan ook interessant na te gaan hoe deze recente daling in langetermijnperspectief bezien kan worden.

\section{Data en methoden}

\section{Gevangenisstatistieken}

Om langetermijnontwikkelingen in vrijheidsbeneming in Nederland te onderzoeken worden in dit artikel gegevens gebruikt van de gevangenisstatistieken die vanaf 1837 systematisch landelijk en jaarlijks verzameld en gepubliceerd zijn (zie voor een overzicht: CBS, 1902; 1986; Van Ruller, 1981b; Van der Bie, 2009). Om de gegevens voor dit artikel te verzamelen en vergelijkbaar te maken is gebruik gemaakt van drie specifieke bronnen. Voor de periode 1837-1977 is gebruik gemaakt van de cijfers van de gevangenisstatistiek die zijn gepresenteerd door Van Ruller (Van Ruller, 1981b). Voor de periode 1977-2016 is gebruik gemaakt van diverse statistische publicaties van het CBS (CBS, diverse jaren). Omdat in de CBS-statistieken sommige gegevens ontbraken, is voor de meest recente jaren (2010-2016) (ook) gebruik gemaakt van statistische overzichten van de Dienst 
Justitiële Inrichtingen (DJI) van het ministerie van Veiligheid en Justitie (DJI, 2012; 2013; 2016).

\section{Afbakening}

Bij de beschrijving van de langetermijntrends wordt in dit artikel - in navolging van Van Ruller (1981a; 1981b) - uitgegaan van een zo ruim mogelijke omschrijving van het begrip 'gevangene': degene die op grond van een strafrechtelijke straf of maatregel in een justitiële inrichting is ingesloten. De ruime uitleg van het begrip gedetineerde, die meer sociologisch/criminologisch dan juridisch van aard is, is gehanteerd om de cijfers van de 20ste en 21ste eeuw zo veel mogelijk vergelijkbaar te maken met de 19de-eeuwse cijfers. Op grond hiervan worden meegeteld: tot (onvoorwaardelijk) gevangenisstraf veroordeelden, voorlopig gehechten, tbr/tbs-gestelden (voor zover in de gevangenisstatistiek opgegeven), minderjarigen op basis van een straf of maatregel ingesloten in rijksinrichtingen voor jeugdigen en verblijvenden in een penitentiair ziekenhuis (zie ook Van Ruller, 1981b, 5). Daarnaast worden ook landlopers en bedelaars in bedelaarskolonies (tot 1886) en rijkswerkinrichtingen (vanaf 1886 tot 1972) in de cijfers meegenomen. Dit gebeurt omdat in de 19de en begin 20ste eeuw een massale insluiting heeft plaatsgevonden van bedelaars en landlopers. Zij verbleven daar op grond van een rechterlijk vonnis en de instellingen hadden duidelijk een gevangeniskarakter. Maar omdat deze vrijheidsbeneming toch een iets ander karakter had, worden de cijferreeksen van aantallen gedetineerden zowel met als zonder landlopers en bedelaars gepresenteerd. In alle analyses worden ingeslotenen in politiebureaus, politieke gevangenen en personen in vreemdelingendetentie buiten beschouwing gelaten.

\section{Kenmerken van vrijheidsbeneming}

Overeenkomstig met de door Van Ruller (1981a; 1981b; 1986) en Van Ruller en Beijers (1995) gehanteerde definities en telmethoden worden in dit artikel langetermijntrends in vrijheidsbeneming beschreven aan de hand van drie kenmerken van het gevangeniswezen:

- De omvang van de gedetineerdenpopulatie. Deze wordt gemeten met behulp van cijfers uit de gevangenisstatistieken over 'de gemiddelde dagbezetting in een jaar', d.w.z. het totaal aantal verblijfsdagen gedeeld door het aantal dagen dat een jaar telt (d.w.z. 365 of 366 in een schrikkeljaar). Een voordeel van dit cijfer is dat het minder aan fluctuatie onderhevig is dan de omvang van de bezetting op een bepaald meetmoment (bijv. 1 januari of 1 september). Overigens verschillen beide soorten cijfers doorgaans nauwelijks van elkaar. In die enkele jaren waar gegevens over de gemiddelde dagbezetting ontbreken, zijn dan ook cijfers van één meetmoment gebruikt. De omvang van de gedetineerdenpopulatie wordt zowel voor de strafinrichtingen apart (1837-2016) als voor de strafinrichtingen, bedelaarskolonies en rijkswerkinrichtingen gezamenlijk (1883-1972) gepresenteerd.

- De omvang van de instroom van gedetineerden. Deze wordt gemeten met cijfers over het aantal personen dat jaarlijks in strafinrichtingen is ingestroomd vanuit de vrije samenleving sinds 1900. Er wordt naar deze maat gekeken omdat 
de omvang van de gedetineerdenpopulatie alleen niet een voldoende maat is voor hoeveel gedetineerden er zijn in een jaar. Een gemiddelde dagbezetting van 1.000 gedetineerden kan bijvoorbeeld betrekking hebben op 1.000 gedetineerden die er een heel jaar zaten, maar ook op 365.000 gevangenen die allen een dag zaten - elke dag dus 1.000 anderen. Dit zijn uiteraard extremen: in 2016 was de gemiddelde bezetting ongeveer 8.000 gedetineerden, terwijl er zo'n 33.000 gedetineerden instroomden.

- De celcapaciteit. Deze wordt gemeten met in de gevangenisstatistiek opgenomen cijfers over het aantal bruikbare cellen in Nederlandse strafinrichtingen. Hierbij wordt ook rekening gehouden met het feit dat sommige cellen niet bruikbaar zijn in verband met onderhoud of verbouwingen.

\section{Absolute en relatieve aantallen}

In dit artikel worden om te beginnen de absolute aantallen gedetineerden of cellen gerapporteerd. Het is echter goed gebruik om bij de analyses van ontwikkelingen in criminaliteit en straffen in een land rekening te houden met veranderingen in de omvang van de (volwassen en/of onder het Wetboek van Strafrecht vallende) bevolking. De consequentie van een correctie voor ontwikkelingen in de omvang van de bevolkingsomvang over een lange periode kan fors zijn: in 1850 had Nederland namelijk nog maar 1,5 miljoen inwoners van 15 jaar en ouder, in 1930 ongeveer 5 miljoen, in 1975 7,5 miljoen en in 2016 al zo'n 11 miljoen inwoners (CBS, StatLine). De omvang van de volwassen bevolking is over de afgelopen 180 jaar dus verachtvoudigd. Daarom worden de aantallen instromende en opgesloten gedetineerden en het aantal beschikbare cellen in dit artikel ook gepresenteerd als relatieve cijfers, d.w.z. per 100.000 inwoners van de bevolking van 15 jaar en ouder.

\section{Resultaten}

Om een helder langetermijnbeeld te verkrijgen van de ontwikkelingen in vrijheidsbeneming in Nederland worden op basis van de gegevens van de gevangenisstatistieken zes grafieken weergegeven voor de periode 1837-2016 (figuur 1,2 en 3). Figuur 1 geeft de ontwikkeling in de omvang van de gedetineerdenpopulatie weer - zowel met betrekking tot het aantal strafgevangenen apart (1837-2016) als met betrekking tot het aantal gedetineerde strafgevangenen, bedelaars en landlopers gezamenlijk (1837-1972). Figuur 2 geeft naast de ontwikkelingen van het aantal strafgevangenen, ook de trend in de beschikbare celcapaciteit weer voor strafgevangenen. Figuur 3 geeft de trends in de omvang van de instroom van strafgevangenen vanuit de vrije samenleving. Alle trends worden zowel in absolute aantallen (de bovenste grafieken) als in relatieve aantallen, d.w.z. per 100.000 inwoners van de bevolking (de onderste grafieken), weergegeven. 

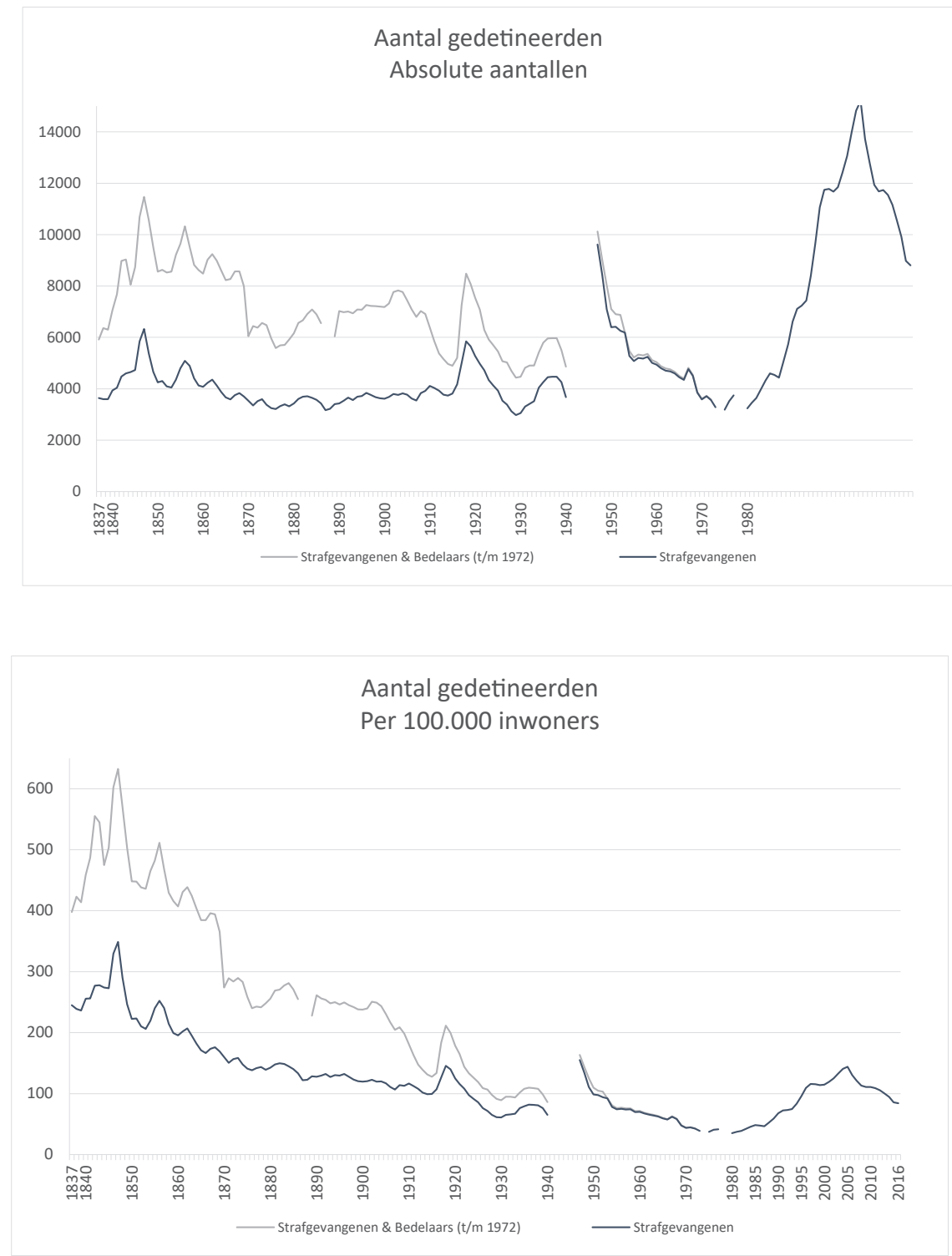

Figuur 1 Ontwikkelingen in de omvang van de gedetineerdenpopulatie in Nederland, 1837-2016 - in absolute aantallen (boven) en relatieve aantallen, d.w.z. per 100.000 inwoners (onder). 
Aantal gedetineerden en detentiecapaciteit Absolute aantallen

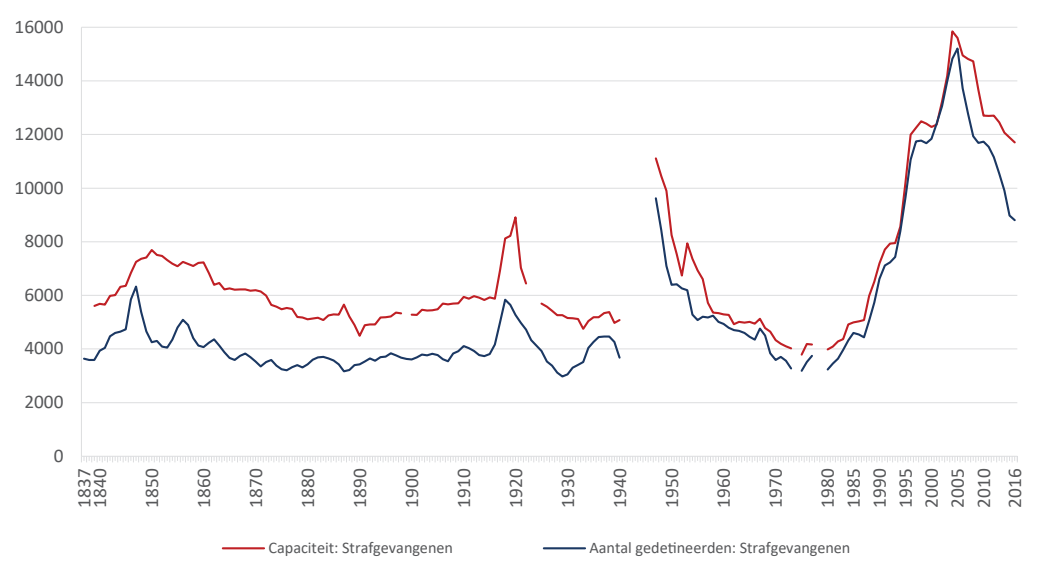

Aantal gedetineerden en detentiecapaciteit

Per 100.000 inwoners

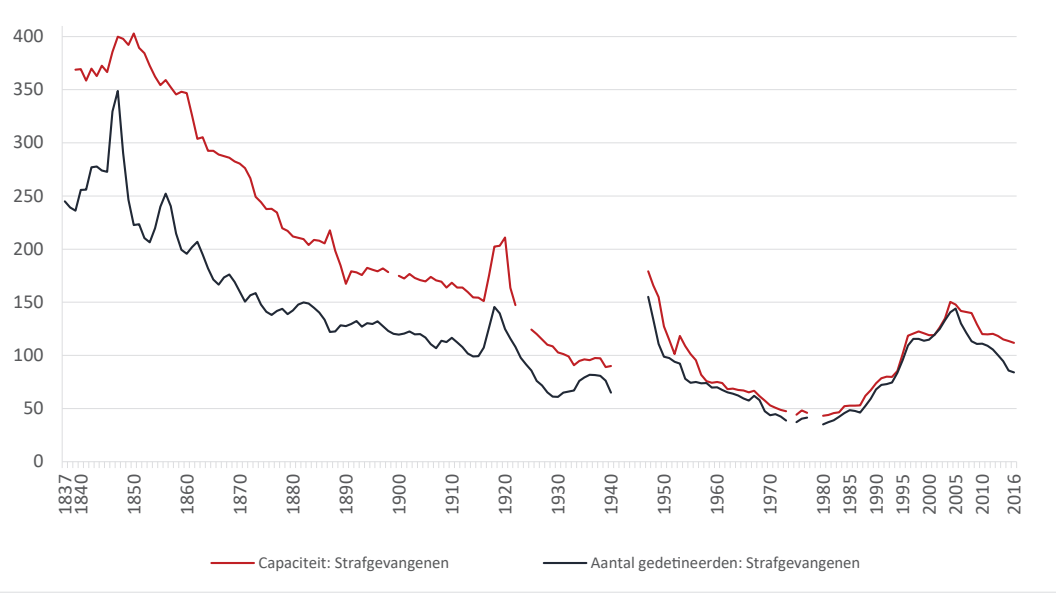

Figuur 2 Ontwikkelingen in de omvang van de gedetineerdenpopulatie en detentiecapaciteit in Nederland, 1837-2016 - in absolute aantallen (boven) en relatieve aantallen, d.w.z. per 100.000 inwoners (onder). 

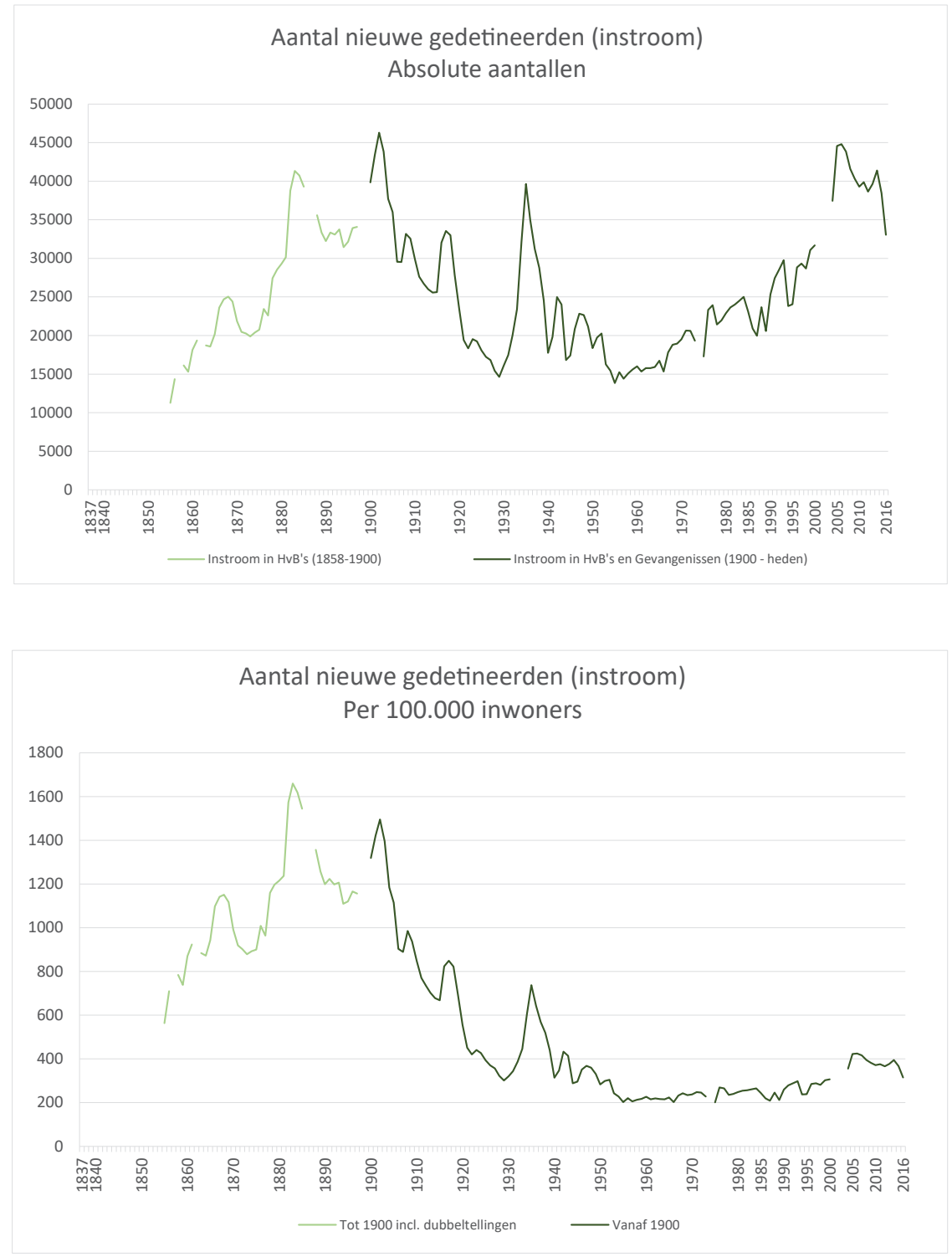

Figuur 3 Ontwikkelingen in de omvang van de instroom van gedetineerden in Nederland, 1837-2016 - in absolute aantallen (boven) en relatieve aantallen, d.w.z. per 100.000 inwoners (onder).

Een globale inspectie van de gepresenteerde figuren maakt twee zaken duidelijk. Allereerst wordt duidelijk dat de ontwikkelingen in aantallen gedetineerden, aantallen cellen en de instroom van gedetineerden in belangrijke mate parallel verlopen - en er voor elk van de drie kenmerken dezelfde relevante perioden te onderscheiden zijn: 1837-1975, 1976-2005 en 2006-2016. Daarnaast maakt een globale 
inspectie helder dat de figuren waarin de ontwikkelingen in absolute aantallen worden geschetst een geheel ander beeld geven dan de figuren waarin trends in relatieve aantallen worden weergegeven. Daarom worden hieronder afzonderlijk de langetermijnontwikkelingen in absolute aantallen en die in relatieve aantallen besproken.

\section{Trends in absolute aantallen}

De bovenste grafieken van figuur 1, 2 en 3 laten zien dat wanneer de absolute aantallen bekeken worden, er tussen 1837 en 2016 drie zeer verschillende perioden te onderscheiden zijn: eerst zo'n 140 jaar waarin de omvang van het gevangeniswezen - op korte fluctuaties na - stabiel was (1837-1975), vervolgens 30 jaar waarin de omvang van het gevangeniswezen is verdrievoudigd (1975-2005), en daarna ruim 10 jaar waarin deze weer fors is gedaald (2006-2016).

In de eerste te onderscheiden periode (1837-1975) was het absolute aantal gedetineerden in ons land zeer stabiel, namelijk ongeveer 3.500 gevangenen. En als gedetineerde bedelaars en landlopers, die in de negentiende eeuw in groten getale werden gevangengehouden, worden meegerekend, dan is er sprake van een lichte daling van het absolute aantal gedetineerden sinds ongeveer 1850. Helder is ook dat het aantal beschikbare cellen zeer stabiel was, en groter dan het aantal gedetineerden: er was een structurele overcapaciteit van een kleine 2.000 cellen. Wel waren er in deze periode opvallende pieken te zien, met name rond de jaren 1847 en 1856 (perioden met uitzonderlijk hoge voedselprijzen en dientengevolge veel vermogenscriminaliteit en repressie daarvan), 1918 (Eerste Wereldoorlog), 1934 (economische crisis) en 1947 (nasleep van de Tweede Wereldoorlog) (Van Ruller, 1981a). Maar na die pieken gingen de aantallen al snel weer terug naar het langetermijngemiddelde - waardoor de pieken dus vooral als kortetermijnfluctuaties gezien kunnen worden. Verder was er tussen 1880 en 1910 een periode met grote aantallen personen die instroomden in strafgevangenissen - maar dat was vooral voor korte duur, want de omvang van de gevangenispopulatie en de omvang van de gevangeniscapaciteit zijn in die periode vrij stabiel.

In de tweede te onderscheiden periode (1975-2005) heeft in ons land een niet eerder waargenomen stijging plaatsgevonden in het absolute aantal gevangenen, namelijk van 3.500 naar 15.000 gedetineerden. De stijging in de populatie van gevangenissen na 1975 ging gepaard met grootscheepse nieuwbouw en een uitbreiding van het aantal beschikbare cellen. De gevangeniscapaciteit heeft dan ook eenzelfde ontwikkeling doorgemaakt als het aantal gevangenen. Opmerkelijk is dat er in deze periode - anders dan de 140 jaren ervoor - geen of nauwelijks reservecapaciteit beschikbaar was, d.w.z. er waren ongeveer evenveel cellen als strafgevangenen (zie de bovenste grafiek in Figuur 2). Het aantal personen dat vanuit de vrije maatschappij jaarlijks instroomde in het gevangeniswezen is in die periode ook fors toegenomen: van 15.000 naar 45.000 .

In de derde te onderscheiden periode (2006-2016) heeft zich een forse daling in de omvang van het gevangeniswezen voorgedaan. $\mathrm{Na} 30$ jaren van forse stijging in het aantal gedetineerden was er rond 2005 een trendbreuk: het aantal gevangenen is daarna gedaald van zo'n 15.000 naar ongeveer 7.500 in 2016. Daarmee is het aantal gedetineerden dus ongeveer gehalveerd ten opzichte van 2005, maar 
(nog) wel tweemaal zo hoog als het historische langetermijngemiddelde in de periode 1837-1975. De ontwikkelingen in detentiecapaciteit laten zien dat het ministerie van Justitie na 2005 de gevangeniscapaciteit in rap tempo verkleind heeft. Ook de instroom is vanaf 2005 fors afgenomen (van 45.000 naar 33.000 per jaar).

\section{Trends in relatieve aantallen (per 100.000 inwoners)}

De vraag is hoe de trends in vrijheidsbeneming eruitzien als rekening gehouden wordt met de verachtvoudiging van de omvang van de bevolking in de afgelopen 180 jaar. De onderste grafieken van figuur 1,2 en 3 geven daarom de trends in relatieve aantallen, d.w.z. per 100.000 inwoners. Uiteraard zijn hierin ook de hierboven beschreven trendbreuken in 1975 en 2005 en belangrijke perioden (1837-1975, 1975-2005, 2006-2016) terug te zien. Zo is ook in deze grafieken een piek te zien in het aantal gedetineerden per hoofd van de bevolking rond de recente eeuwwisseling op een niveau dat sinds 1920 niet meer was voorgekomen. Echter, het totaalbeeld in de onderste grafieken is heel anders dan in de - hierboven besproken - bovenste grafieken.

De langetermijnontwikkelingen in de onderste grafieken laten zich vooral karakteriseren als een continue structurele afname van de omvang van het gevangeniswezen. Het aantal gedetineerden in verhouding tot de omvang van de bevolking is de afgelopen 180 jaar fors afgenomen. Rond 1850 waren er ongeveer 350 strafgevangenen per 100.000 inwoners en in 2016 nog slechts zo'n 80. De continue langetermijndaling is ook duidelijk zichtbaar in de afname in de celcapaciteit per 100.000 inwoners - die in de afgelopen 180 jaar eveneens zevenmaal zo klein is geworden. Ook is de daling te zien in de continu afgenomen instroom van gedetineerden sinds het midden van de negentiende eeuw.

De langetermijnontwikkelingen in relatieve aantallen laten zich dan ook vooral karakteriseren als een continue structurele afname van de omvang van het gevangeniswezen: als rekening wordt gehouden met de enorme groei van de Nederlandse bevolking, is er sprake van een structurele afname in vrijheidsbeneming over de afgelopen 180 jaar. Inwoners van Nederland hebben steeds minder kans gedetineerd te zijn.

\section{Conclusie}

De hierboven beschreven bevindingen roepen natuurlijk de vraag op: hoe kunnen zowel de trends in absolute aantallen als die in relatieve aantallen worden verklaard? Gezien de uiteenlopende uitkomsten zouden de antwoorden het liefst zowel de structurele langetermijndaling in relatieve aantallen gevangenen als de meer kortetermijnveranderingen in absolute aantallen verklaren.

Om historische veranderingen in vrijheidsbeneming te verklaren kan aan de ene kant gebruik worden gemaakt van de 'grote' interpretatiekaders (zie ook Van Ruller, 2009). Zo'n breed interpretatiekader zou het (neo)marxistisch kader kunnen zijn dat veronderstelt dat criminaliteit het gevolg is van de achterstelling van 
sociaal zwakkeren, die door de sociaaleconomische omstandigheden hun toevlucht (moeten) nemen tot het overtreden van normen en wetten.

Een ander breed interpretatiekader dat gebruikt zou kunnen worden, is de theorie over de langetermijncivilisatieprocessen, zoals oorspronkelijk geformuleerd door Elias (1982 [1939]) en later uitgewerkt in studies over de geschiedenis van vrijheidsbeneming in Nederland (Franke, 1990). Volgens dit kader is er sprake van een langetermijncivilisatieproces in de manier waarop mensen in westerse samenlevingen met elkaar omgaan. In de loop der eeuwen zijn mensen hun impulsen meer gaan beheersen, en is er een toenemende consideratie met anderen. De langetermijndaling in relatieve aantallen gedetineerden lijkt in overeenstemming met dit civilisatie-interpretatiekader.

De hierboven besproken brede theoretische interpretatiekaders bieden in principe goede mogelijkheden om verklaringen af te leiden voor langetermijnveranderingen in vrijheidsbeneming in Nederland. Ingewikkeld is wel dat deze kaders breed en weinig precies zijn, en daardoor lastig empirisch te toetsen. Op basis van eenvoudige redeneringen zijn echter diverse concrete en toetsbare hypothesen af te leiden. Verschillende criminologen hebben dit de afgelopen decennia ook al gedaan (zie bijv. Downs \& Van Swaaningen, 2007; Buruma, 2016; Van Ruller \& Beijers, 1995; Tonry \& Bijleveld, 2006; Tonry, 2014). Tabel 1 geeft - mede op basis van eerder geformuleerde verwachtingen (zie met name Van Ruller \& Beijers, 1995) - een korte lijst met hypothesen, waarbij zeker geen volledigheid verondersteld en geclaimd wordt.

Tabel 1 Hypothesen ter verklaring van veranderingen in vrijheidsbeneming in Nederland

\section{De omvang van de gedetineerdenpopulatie en de instroom van gedetineerden in een jaar zal groter zijn als in dat jaar (of in de daaraan voorgaande jaren) ...}

\section{Oorzaken}

(Oorzaken van) normafwijkend gedrag

- de samenleving grotere aanleidingen kent om criminaliteit te plegen (armoede, desorganisatie, oorlogen)

- inwoners minder zelfdwang en zelfcontrole hebben (bijv. i.v.m. de gecompliceerde samenleving - zie Elias, 1982 [1939])

- de omvang van de gepleegde criminaliteit groter is

- de criminaliteit van ernstigere aard is (bijv. als er meer zware en drugscriminaliteit is)

Demografische factoren

- de omvang van de bevolking groter is (d.w.z. als er meer inwoners zijn)

- het aandeel van jonge mannen in de bevolking groter is (die relatief veel criminaliteit plegen)

- het aantal veroordeelden dat niet voldoet aan de opgelegde (bijzondere) voorwaarden groter is

Strafklimaat

- in het maatschappelijke debat de nadruk meer ligt op vergelding en preventie en minder op resocialisatie

- de 'waarde van gevangenisstraf' als groter wordt gevoeld

- in het politieke debat meer belang wordt gegeven aan de ervaringen van slachtoffers van criminaliteit 


\section{Mechanismen (juridische, organisatorische en technische veranderingen in het strafrechtelijk systeem)}

\section{Strafbaarstelling en strafvordering}

- meer soorten gedragingen strafbaar zijn gesteld in het Wetboek van Strafrecht (Sr) en overige wetten

- de wettelijke, maximaal mogelijke straffen (strafdreigingen) groter zijn

- $\quad$ er minder (juridische) mogelijkheden zijn zaken buiten het strafrecht af te doen

- er minder (juridische) mogelijkheden zijn zaken met andere sancties dan vrijheidsstraffen (non-custodial sentences) af te doen (boetes, gevangenisstraffen, alternatieve straffen en maatregelen)

\section{Opsporing}

_ $\quad$ meer aangifte bij de politie gedaan wordt door slachtoffers en burgers

- meer delicten worden geregistreerd door de politie

- meer delicten worden opgehelderd door de politie

- $\quad$ meer delicten worden doorgestuurd ter vervolging door het OM (i.p.v. als politiesepot worden afgedaan)

\section{Vervolging}

- $\quad$ een minder groot deel van de zaken door het OM wordt geseponeerd

- de (juridische) mogelijkheden om zaken buiten het strafrecht af te doen (bijv. via Halt of OM-transacties) minder vaak worden benut

\section{Berechting}

- de (juridische) mogelijkheden om zaken met andersoortige dan vrijheidsstraffen (non-custodial sentences) af te doen minder vaak worden benut

- meer voorwaardelijke straffen (en minder onvoorwaardelijke (gevangenis)straffen) worden opgelegd

- de duur van de opgelegde vrijheidsstraffen groter is

Uitvoering van sancties

- er vaker gedetineerden aan het eind van hun detentie voorwaardelijk in vrijheid worden gesteld

- $\quad$ er strenger wordt opgetreden als veroordeelden niet voldoen aan opgelegde (bijzondere) voorwaarden

- $\quad$ er meer overcapaciteit aan gevangeniscellen is

Bij de presentatie van deze hypothesen wordt - in navolging van Van Ruller en Beijers (1995) - onderscheid gemaakt tussen 'oorzaken' en 'mechanismen'. Met oorzaken worden bedoeld de achterliggende veranderingen in de Nederlandse samenleving (incl. crimineel gedrag) en de mentaliteit en cultuur van de verschillende betrokkenen (bijv. burgers, politici, wetgevers, actoren in de strafrechtsketen) die van invloed zijn geweest. Met mechanismen worden met name de juridische, organisatorische en technische veranderingen in de diverse fasen van het strafrechtelijk systeem bedoeld, waardoor de geschetste ontwikkelingen mogelijk zijn geworden. De idee is dat mechanismen trends in vrijheidsbeneming mogelijk maken, maar geen zelfstandige causale werking hebben.

De meeste van de in tabel 1 gepresenteerde hypothesen kunnen zonder problemen adequaat empirisch worden getoetst. Verrassend genoeg is dat tot dusverre niet of nauwelijks gebeurd. Deze lacune is opmerkelijk, omdat de historische gegevens benodigd voor empirische toetsingen wel voorhanden zijn - d.w.z. soms wellicht niet voor de gehele periode vanaf 1837 tot nu, maar vaak wel voor grote delen daarvan. Zo bevatten de gevangenisstatistieken, rechtbankstatistieken, 
OM-statistieken en politiestatistieken zeer bruikbare gegevens over lange perioden. Verder zijn over de laatste 40 jaar bruikbare gegevens beschikbaar van slachtofferenquêtes, die inzicht geven in de door de bevolking ondervonden criminaliteit en de reacties van het strafrechtelijk systeem. Daarnaast bieden historische krantenberichten, dossiers van verzekeringsmaatschappijen en ziekenhuizen, en ook verkiezingsprogramma's van politieke partijen en verslagen van politieke vergaderingen inzicht in de ontwikkeling van maatschappelijke en culturele oorzaken en (strafrechtelijke) mechanismen achter trends in vrijheidsbeneming in Nederland.

Hopelijk is dit artikel dan ook aanleiding om in toekomstig onderzoek de diverse mogelijke verklaringen van langetermijntrends in vrijheidsbeneming in ons land zo goed mogelijk empirisch te toetsen.

\section{Literatuur}

Bie, R.J. van der (2009). De gerechtelijke statistieken van het CBS tot 1940. In: G.A. Van Syngehel (red.). Broncommentaren 7. Bronnen voor de criminaliteit en strafrechtspleging vanaf 1811 tot heden. Den Haag: Instituut voor Nederlandse Geschiedenis, 243-286.

Buruma, Y. (2016). Wat is een goede rechter? Een mentaliteitsgeschiedenis (1900-2020). Nijmegen: Centrum voor Postacademisch Juridisch Onderwijs - Radboud Universiteit.

CBS (Centraal Bureau voor de Statistiek). (1902). Bijdrage tot de statistiek van Nederland. Nieuwe volgreeks. Geschiedenis van de statistiek in het Koninkrijk der Nederlanden. Den Haag: Gebr. Belinfante.

CBS (Centraal Bureau voor de Statistiek). (1986). Honderd jaar strafrecht in statistieken, 1886-1986. Den Haag: Staatsuitgeverij.

CBS (Centraal Bureau voor de Statistiek). (2017). Criminaliteit en rechtshandhaving 2016. Den Haag.

DJI (Dienst Justitiële Inrichtingen). (2012). Gevangeniswezen in getal, 2007-2011. Den Haag.

DJI (Dienst Justitiële Inrichtingen). (2013). Gevangeniswezen in getal, 2008-2012. Den Haag.

DJI (Dienst Justitiële Inrichtingen). (2016). DJI in getal, 2011-2015. Den Haag.

Downs, D. \& Swaaningen, R. van (2007). The road to dystopia? Changes in the penal climate of the Netherlands. In: M. Tonry \& C. Bijleveld (eds.). Crime and justice in the Netherlands. Chicago/London: The University of Chicago Press, 31-72.

Elias, N. (1982 [1939]). Het civilisatieproces. Sociogenetische en psychogenetische onderzoekingen. Utrecht: Het Spectrum.

Fiselier, J.P.S. (1987). De hypothese van het stabiele straf-niveau. In: G.J.M. Corstens e.a. (red.). Straffen in gerechtigheid; opstellen over sancties en executie (uitgegeven ter nagedachtenis aan prof. mr. W.H.A. Jonkers). Arnhem: Gouda Quint, 353-370.

Fiselier, J.P.S. (1992). A test of the stability of punishment hypothesis: the Dutch case. Journal of Quantitative Criminology, 8, 133-151.

Franke, H. (1990). Twee eeuwen gevangen. Misdaad en straf in Nederland. Utrecht: Het Spectrum.

Ruller, S. van (1981a). Het aantal gevangenen in Nederland sinds 1837. Een analyse van 140 jaar gevangenisstatistieken. Tijdschrift voor Criminologie, 23, 209-223. 
Ruller, S. van (1981b). Het getal der gevangenen, 1837-1977. De omvang van de bevolking van de Nederlandse strafinrichtingen in de afgelopen 140 jaar. Amsterdam: Criminologisch Instituut Vrije Universiteit Amsterdam.

Ruller, S. van (1986). Honderd jaar vrijheidsbeneming in cijfers. In: D.H. de Jong, J.L. van der Neut \& J.J.J. Tulkens (red.). De vrijheidsstraf. Arnhem: Gouda Quint, 57-76.

Ruller, S. van (2003). De recente groei van het gevangeniswezen in historisch perspectief. Tijdschrift voor Criminologie, 45, 220-225.

Ruller, S. van (2009). Geschiedenis van de vrijheidsbeneming. In: E.R. Muller \& P.C. Vegter (red.). Detentie. Gevangen in Nederland. Alphen aan den Rijn: Kluwer.

Ruller, S. van \& Beijers, W.M.E.H. (1995). Trends in detentie. Twee eeuwen gevangenisstatistiek. Justitiële verkenningen, 21, 35-52.

Tonry, M. (2014). Why crime rates are falling throughout the Western world. Crime \& Justice, 43, 1-63.

Tonry, M. \& Bijleveld, C. (2006). Crime, criminal justice, and criminology in the Netherlands. In: M. Tonry \& C. Bijleveld (eds.). Crime and justice in the Netherlands. Chicago/London: The University of Chicago Press, 1-30. 